\title{
Exogenous Nitric Oxide Pretreatment Enhances Chilling Tolerance of Anthurium
}

\author{
Lijian Liang, Yanming Deng, Xiaobo Sun, Xinping Jia, and Jiale Su${ }^{1}$ \\ Provincial Key Laboratory for Horticultural Crop Genetic Improvement, Institute of Leisure \\ Agriculture, Jiangsu Academy of Agricultural Sciences, Nanjing 210014, Jiangsu, People's Republic \\ of China
}

\begin{abstract}
AdDitional INDEX words. antioxidant enzymes, chlorophyll content, malondialdehyde, photochemical efficiency, proline, reactive oxygen species

Abstract. Nitric oxide (NO) is well known for its multifaceted physiological roles as a signaling molecule in plants. Previous studies have indicated that exogenous application of NO may be useful for alleviating chilling injury (CI) in fruits and vegetables. However, the potential role and mechanism of NO in mitigating chilling stress in anthurium (Anthurium andraeanum) remain unclear. In this study, physiological and biochemical analysis were performed to investigate the effects of exogenous NO in alleviating CI in anthurium. Anthurium seedling plants were treated with the NO donor sodium nitroprusside (SNP) at four concentrations $(0,0.2,0.4$, and $0.8 \mathrm{~mm})$ and stored at $12 / 5^{\circ} \mathrm{C}(\mathrm{day} /$ night) for 15 day. The results showed that exogenous SNP mitigated the adverse effects of chilling on anthurium, and the most effective concentration was $0.2 \mathrm{~mm}$. In addition, NO effectively improved the CI index, malondialdehyde (MDA) content, electrolyte leakage, photochemical efficiency $\left(F_{\mathrm{v}} / F_{\mathrm{m}}\right)$, and chlorophyll loss of anthurium during low temperatures. Pretreatment with SNP also increased the activity of antioxidant enzymes such as superoxide dismutase (SOD), catalase (CAT), peroxidase (POD), and ascorbate peroxidase (APX); the content of antioxidants including glutathione (GSH), ascorbic acid (AsA), and phenolics; and reduced the accumulation of hydrogen peroxide and $\mathrm{O}_{2}^{-}$. SNP pretreatment at $0.2 \mathrm{~mm}$ also significantly promoted the accumulation of proline, increased the activity of $\Delta 1$-pyrroline-5-carboxylate synthetase (P5CS), and reduced the activity of proline dehydrogenase (PDH), when compared with control $(0 \mathrm{~mm} \mathrm{SNP} \rightarrow$ Chilling) under chilling stress. These results indicated that NO could enhance the chilling tolerance of anthurium by elicitation of an antioxidant response and proline accumulation for maintaining cell membrane integrity.
\end{abstract}

$\mathrm{CI}$ is one of the main restrictive factors affecting the growth and use of tropical plants in temperate and subtropical areas. Under chilling stress condition, physiological and biochemical processes, including growth rate, photosynthesis, respiration, nutrient absorption, and transport, are impaired (Aghdam and Bodbodak, 2013; Kratsch and Wise, 2000). It also caused membrane system dysfunction and accumulation of reactive oxygen species (ROS) such as $\mathrm{H}_{2} \mathrm{O}_{2}$ and superoxide $\left(\mathrm{O}_{2}{ }^{-}\right)$ (Aghdam and Bodbodak, 2013; Rui et al., 2010). For example, cell membrane phase from a fluid liquid crystalline shifted to a rigid solid gel under chilling temperature, leading to diminishing membrane selective permeability (Aghdam et al., 2013). The excessive ROS associated with the incidence of CI are crucial sources of oxidative stress (Ruelland et al., 2009; Suzuki and Mittler, 2006). They can rapidly react with various molecules, resulting in membrane lipid peroxidation, protein degradation, and nucleic acid damage (Scandalios, 1993; Sharma et al., 2012). To defend against these damaging effects, plants have evolved two kinds of antioxidative systems to scavenge ROS. One is the antioxidant enzymes, including SOD (EC 1.15.1.1), CAT (EC 1.11.1.6), POD (EC 1.11.1.7), and APX (EC 1.11.1.11) (Hossain et al., 2010). The other is the nonenzymatic antioxidants, such as proline, reduced GSH, AsA, and phenolics (Blokhina et al., 2003; Szabados and

Received for publication 17 July 2017. Accepted for publication 24 Oct. 2017. This work was supported by the Fund for Independent Innovation of Agricultural Sciences in Jiangsu Province (CX(14)5053), the Jiangsu Science and Technology Support Program (Grant No. BE2014408), and the National Science and Technology Support Program (Grant No. 2013BAD01B070403).

${ }^{1}$ Corresponding author. E-mail: potted_flowers@163.com.
Savouré, 2010; Tsantili et al., 2010). It is well recognized that both osmoprotective mechanism and antioxidation mechanism contribute in CI resistance of plants, even at extreme low temperatures (Javadian et al., 2010; Xu et al., 2012).

Some signaling molecules, such as NO, salicylic acid (SA), jasmonic acid, and hydrogen sulfide have been found to regulate the physiological processes of plants (Luo et al., 2015; Promyou et al., 2012; Siboza et al., 2014). NO is acclaimed to be involved in the modulation of various physiological processes during the entire life of the plant (Mur et al., 2012). For example, it was found to play a crucial role in the stimulation of seed and pollen germination, modulation of plant growth and development, regulation of cell elongation, floral regulation, mediation of stomatal movement, photosynthesis regulation, ripening of fruit and senescence of organs, and so on (Procházková et al., 2015). Moreover, NO is demonstrated as one of the key components of plant responses to abiotic stress including CI (Qiao and Fan, 2008; Siddiqui et al., 2011). Using fumigation with $\mathrm{NO}$ gas or treatments with NO-releasing chemicals, several studies have correlated the capacity of NO to prevent CI with the upregulation of the antioxidant defense (Singh et al., 2009; Xu et al., 2012). For example, it has been demonstrated that NO can regulate plant antioxidant systems, enhance the removal of ROS, stimulate proline accumulation, reduce the cellular membrane damage caused by low temperatures, and improve chilling tolerance (Wang et al., 2013; Wu et al., 2014). In addition, NO has also been selected as a promising strategy for combating chilling stresses encountered by various horticultural plants, such as peach (Prunus persica), cucumber (Cucumis sativus), and chinese cabbage (Brassica campestris ssp. chinensis) (Fan et al., 2014; Yang 
et al., 2011; Zhu et al., 2010). Nevertheless, the understanding of the interaction between NO and chilling stress tolerance remains scarce.

As an economically important tropical ornamental crop, anthurium stands out among most cultivated tropical flowers for its exquisiteness, durability, and long vase-life (Gantait and Mandal, 2010). Anthurium belongs to the largest genus of Araceae family that encompasses over 1500 species, of which 600 species are from tropical America (Venkat et al., 2014). Anthurium plants are particularly susceptible to low temperatures. They will stop growing when subjected to cold conditions and often exhibit additional symptoms including leaf etiolation, spadix wilting, and spathe browning (Aghdam et al., 2015). Besides, they are irreversibly injured by long-term exposure to temperatures lower than $6^{\circ} \mathrm{C}$. In temperate and cold areas, a much greater risk of cold stress occurs in the supply of anthurium plants, especially in the process of production and transportation (Tian et al., 2013). Thus, the improvement of chilling stress tolerance in anthurium may not only significantly increase its production and extend its shelf life but also reduce the economic loss.

Previously, the application of exogenous SA and $\gamma$-aminobutyric acid for improving the CI tolerance in anthurium has been studied (Aghdam et al., 2015; Promyou et al., 2012). Here, the beneficial effects of exogenous NO pretreatment on alleviating CI in anthurium plants were investigated. Our results might provide some valuable information of NO involved in chilling stress tolerance to help develop methods to reduce CI in anthurium.

\section{Materials and Methods}

Plant materials and treatments. Anthurium plants were obtained from commercial growers in Guangzhou province and preserved in greenhouses in the Anthurium Germplasm Resource Preserve Center (Jiangsu Academy of Agricultural Sciences, Nanjing, China). The experiment was performed from Sept. to Dec. 2015. Seedling plants (360) showing the same or similar sizes were selected and cultured in plastic pots (80 $\mathrm{mm}$ height $\times 90 \mathrm{~mm}$ diameter, with three plant seedlings per pot) containing peatmoss. The plants were placed in a growth chamber and fertilized every 1 week with $20 \mathrm{~N}-4.4 \mathrm{P}-16.6 \mathrm{~K}$ fertilizer solution (1:3000 dilution) for $20 \mathrm{~d}$ under the following conditions: temperature $25 / 18{ }^{\circ} \mathrm{C}$ (day/night), $12 / 12 \mathrm{~h}$ photoperiod (irradiance of $200 \mu \mathrm{mol} \cdot \mathrm{m}^{-2} \cdot \mathrm{s}^{-1}$ ), and $70 \%$ relative humidity. Meanwhile, the plants were watered in $10 \mathrm{~mL}$ every 3 d. Subsequently, the plants (about 12-15 cm height) were randomly divided into four groups, and the whole plant seedlings in each group were sprayed with different concentrations $(0,0.2,0.4$, and $0.8 \mathrm{~mm})$ of SNP (a common NO donor) as a pretreatment for three times at 2-d intervals. After that, chilling stress was performed by decreasing the temperature to $12 / 5^{\circ} \mathrm{C}$ (day/night) for the indicated time points $(0,3,6,9,12$, and $15 \mathrm{~d})$. Then, $12-15$ leaves (10-12 cm length, 5-6 cm width) at the same position of anthurium plants were harvested and stored at $-80{ }^{\circ} \mathrm{C}$ immediately for the further analysis. The experiments were repeated at three times with similar results.

CI INDEX DETERMINATION. CI index was evaluated by visualizing the severity of necrotic tissues on the leaves of 30 individual plants using the following scale: $1=$ no CI, $2=$ mild injury $(1 \%$ to $20 \%$ necrotic area), $3=$ moderate injury $(21 \%$ to $50 \%$ necrotic area), $4=$ severe injury ( $51 \%$ to $80 \%$ necrotic area $)$, and $5=$ very severe injury $(81 \%$ to $100 \%$ necrotic area), according to the method of Aghdam et al. (2015). The CI index was calculated according to the following equation: $\mathrm{CI}$ index $=\Sigma$ (number on $\mathrm{CI}$ scale $\times$ the number of plants at that number on the $\mathrm{CI}$ scale)/total number of plants.

PhotosynthetiC PIGMENTS AND CHLOROPHYLL FLUORESCENCE DETERMINATION. The chlorophyll $a(\mathrm{Chl} a)$, chlorophyll $b(\mathrm{Chl} b)$, total chlorophyll, and carotenoids (Car) were determined according to the method of Lichtenthaler (1987) with minor modifications. Twenty leaf discs $(0.5 \mathrm{~cm}$ diameter $)$ were excised from the uppermost fully expanded leaves of 10 plants selected randomly from each group. Then, $20 \mathrm{~mL}$ acetone (80\%) was added for the extraction of photosynthetic pigments. After incubating $24 \mathrm{~h}$ in dark conditions, the absorbance of the extract was measured using a spectrophotometer (UH-5300; Hitachi, Tokyo, Japan) at 470, 645, and $663 \mathrm{~nm}$. Concentrations of Chl $a$, Chl $b$, total Chl, and Car were then calculated.

Leaf chlorophyll fluorescence was measured by a chlorophyll fluorometer (Plant Efficiency Analyzer; Hansatech, Norfolk, UK). Readings were taken from 5-mm-diameter leaf disks after dark adaptation for $30 \mathrm{~min}$. The ratio of $F_{\mathrm{v}} / F_{\mathrm{m}}$ represents the maximum $F_{\mathrm{v}} / F_{\mathrm{m}}$ of photosystem II (PS II), and was calculated according to Krüger et al. (1997).

MEMBRANe PERMEABILITy AND LIPID PEROXIDATION DETERMINATION. Membrane permeability, expressed by relative electrolyte leakage, was determined by a modified method (Promyou et al., 2012). Twenty discs $(2 \mathrm{~mm}$ thick $\times 6 \mathrm{~mm}$ diameter) were excised from the leaves with a cork borer. After being rinsed three times in deionized water, they were incubated in $20 \mathrm{~mL}$ deionized water and shaken for $1 \mathrm{~h}$ at 100 cycles per minute. Conductivity of the solution was detected using a conductivity meter (DDSJ-308A; Leici, Shanghai, China). Total conductivity was determined after boiling the flasks for $20 \mathrm{~min}$ to release electrolytes. Relative electrolyte leakage was expressed as a percentage of total conductivity.

The level of lipid peroxidation was expressed as the MDA content using the thiobarbituric acid (TBA) method described by Hodges et al. (1999) with a slight modification. Leaves $(0.5 \mathrm{~g})$ were homogenized with $10 \mathrm{~mL}$ of $5 \%(\mathrm{w} / \mathrm{v})$ trichloroacetic acid (TCA) and centrifuged at $12,000 \mathrm{~g}_{\mathrm{n}}$ for $15 \mathrm{~min}$. TBA reactivity was determined by adding $2 \mathrm{~mL}$ of $0.67 \%$ TBA in $10 \%$ TCA to $2 \mathrm{~mL}$ of the supernatant. The mixture was held in a bath containing boiling water for $20 \mathrm{~min}$, quickly cooled, and then centrifuged at $12,000 \mathrm{~g}_{\mathrm{n}}$ for $10 \mathrm{~min}$. Absorbance was measured at $532 \mathrm{~nm}$ and corrected for nonspecific turbidity by subtracting the absorbance at $600 \mathrm{~nm}$ and interference generated by TBA-sucrose complexes at $450 \mathrm{~nm}$. The MDA content was expressed as nanomoles per gram fresh weight (FW).

Determination of AsA, GSH, total PHENOLS, AND PROLINE CONTENTS. To determine the contents of AsA and GSH, $0.5 \mathrm{~g}$ leaf was homogenized in 5\% (w/v) ice-cold TCA and then centrifuged at $12,000 \mathrm{~g}_{\mathrm{n}}$ for $20 \mathrm{~min}$ at $4{ }^{\circ} \mathrm{C}$. The supernatant was used for the AsA and GSH assays. AsA and GSH contents were measured according to Tanaka et al. (1985) and Lin et al. (2012), respectively.

The total phenolics in the leaves were measured according to Chen et al. (2008) with modification. Briefly, $1 \mathrm{~g}$ plant material was homogenized and extracted with $8 \mathrm{~mL}$ of $80 \%$ methanol for $24 \mathrm{~h}$ in the dark. The solution was centrifuged at $10,000 \mathrm{~g}_{\mathrm{n}}$ for $10 \mathrm{~min}$. The total phenolic concentration in the supernatant was determined colorimetrically at $750 \mathrm{~nm}$. The results were expressed as milligrams gallic acid equivalents per gram FW. 
Proline was assayed using the method of Zhao et al. (2009). Leaf samples $(0.5 \mathrm{~g})$ were homogenized in $3 \%$ sulfosalicylic acid and centrifuged at $10,000 g_{n}$ for $10 \mathrm{~min}$. Two milliliters of extract was incubated with $2 \mathrm{~mL}$ of $2.5 \%$ ninhydrin reagent and $2 \mathrm{~mL}$ of glacial acetic acid at $100{ }^{\circ} \mathrm{C}$ for $30 \mathrm{~min}$. Then, toluene $(4 \mathrm{~mL})$ was added into the mixture after the solution was cooled. The absorbance of the organic phase was recorded at $520 \mathrm{~nm}$. L-proline was used as the standard.

Determination of $\mathrm{O}_{2}^{-}$Production RAte AND $\mathrm{H}_{2} \mathrm{O}_{2}$ CONTENTS. Leaf samples $(1.0 \mathrm{~g})$ were homogenized in $3 \mathrm{~mL}$ of cold $50 \mathrm{~mm}$ phosphate buffer $(\mathrm{pH} 7.0)$ containing $1 \%(\mathrm{w} / \mathrm{v})$ ethylenediaminetetraacetic acid (EDTA), and then centrifuged at $12,000 g_{\mathrm{n}}$ at $4{ }^{\circ} \mathrm{C}$ for $10 \mathrm{~min}$. The $\mathrm{O}_{2}^{-}$production rate was measured by monitoring nitrite formation from hydroxylamine in the presence of $\mathrm{O}_{2}{ }^{-}$as described previously (Xu et al., 2012). $\mathrm{NaNO}_{2}$ was used as the standard.

The content of $\mathrm{H}_{2} \mathrm{O}_{2}$ was determined by the method of Ferguson et al. (1983). Leaf samples $(0.5 \mathrm{~g})$ were homogenized in $5 \mathrm{~mL}$ cold acetone and centrifuged at $12,000 \mathrm{~g}_{\mathrm{n}}$ for $10 \mathrm{~min}$. The supernatant $(1 \mathrm{~mL})$ was mixed with $0.1 \mathrm{~mL}$ of $20 \% \mathrm{TiCl}_{4}$ and $0.2 \mathrm{~mL}$ of concentrated $\mathrm{NH}_{4} \mathrm{OH}$ solution. After shaking and reacting for $5 \mathrm{~min}$, the mixture was then centrifuged $\left(12,000 \mathrm{~g}_{\mathrm{n}}\right)$ at $4{ }^{\circ} \mathrm{C}$ for $15 \mathrm{~min}$, and the precipitates were washed repeatedly with cold acetone until the acetone was colorless. The precipitates were dissolved in $4 \mathrm{~mL}$ of $2 \mathrm{M} \mathrm{H}_{2} \mathrm{SO}_{4}$. The absorbance was measured at $415 \mathrm{~nm} . \mathrm{H}_{2} \mathrm{O}_{2}$ content was calculated from a standard curve prepared in a similar way.

Measurements of SOD, CAT, POD, And APX activities. For the determination of the enzyme activities, $0.5 \mathrm{~g}$ leaves were homogenized with ice-cold $50 \mathrm{~mm}$ phosphate buffer $(\mathrm{pH}$ 7.0) containing $0.1 \mathrm{~mm}$ EDTA and $1 \%(\mathrm{w} / \mathrm{v})$ polyvinylpyrrolidone (PVP) in a chilled mortar and pestle. The homogenate was centrifuged at $12,000 \mathrm{~g}_{\mathrm{n}}$ for $20 \mathrm{~min}$, and the supernatant was collected for determination of enzyme activities. Total protein content was determined according to the method of Bradford (1976) using bovine serum albumin (BSA) as a standard sample.

SOD activity was analyzed by measuring its ability to inhibit the photoreduction of nitrobluetetrazolium (NBT) following the method of Beyer and Fridovich (1987). One unit of SOD activity was defined as the amount of enzyme that would inhibit $50 \%$ of NBT photoreduction at $560 \mathrm{~nm}$. CAT activity was measured by following the decline in absorbance at $240 \mathrm{~nm}$ due to the consumption of $\mathrm{H}_{2} \mathrm{O}_{2}$ (Patra et al., 1978). One unit of CAT activity was defined as the amount of enzyme required to degrade $0.1 \mu \mathrm{mol} \mathrm{H}_{2} \mathrm{O}_{2}$ per minute. POD activity was measured by following the change in absorption at $470 \mathrm{~nm}$ due to guaiacol oxidation (Polle et al., 1994). One unit of POD activity was defined as the amount of enzyme required for formation of $1 \mu \mathrm{mol}$ guaiacol per minute. APX activity was measured following the decrease in absorbance at $290 \mathrm{~nm}$ due to the oxidation of ascorbate (Nakano and Asada, 1981). One unit of APX activity was defined as the amount of enzyme that oxidized $1 \mu \mathrm{mol}$ of ascorbate per minute.

Measurements of phenylalanine ammonia lyase (PAL) AND POLPHENOL OXIDASE (PPO) ACTIVITIES. PAL was extracted and assayed as described by Wang et al. (2013). Leaf samples $(0.5 \mathrm{~g})$ were homogenized in $5 \mathrm{~mL}$ of $50 \mathrm{~mm}$ phosphate buffer (pH 8.8) on ice and centrifuged at $12,000 \mathrm{~g}_{\mathrm{n}}$ for $10 \mathrm{~min}$ at $4{ }^{\circ} \mathrm{C}$. PAL activity was determined using the supernatant, $0.5 \mathrm{~mL}$ of which was added to a reaction mixture containing $1 \mathrm{~mL}$ of $200 \mathrm{~mm}$ L-phenylalanine and $3 \mathrm{~mL}$ of $50 \mathrm{~mm}$ borate buffer $(\mathrm{pH}$
8.5). After incubating the mixture at $30{ }^{\circ} \mathrm{C}$ for $1 \mathrm{~h}$, the reaction was stopped by adding $0.1 \mathrm{~mL}$ of $5 \mathrm{~mm} \mathrm{HCl}$. PAL activity was calculated from the absorbance of the assay mixture at $290 \mathrm{~nm}$ based on the production of cinnamic acid. One unit of PAL activity was defined as the amount of enzyme that produces $1 \mu \mathrm{mol}$ of cinnamic acid per hour. The PPO was extracted and assayed using the method of Nguyen et al. (2003). One gram of leaves was homogenized in $10 \mathrm{~mL}$ of phosphate buffer (100 mM, pH 7.8) with 1\% PVP, and the solution was then centrifuged at $12,000 \mathrm{~g}_{\mathrm{n}}$ for $10 \mathrm{~min}$ at $4{ }^{\circ} \mathrm{C}$. The supernatant was collected as a crude PPO extraction. The reaction mixture contained $200 \mathrm{~mm}$ catechol in $50 \mathrm{~mm}$ phosphate buffer ( $\mathrm{pH}$ 6.0). One unit of PPO activity was defined as the amount of enzyme that produces $1 \mu \mathrm{mol}$ of quinone per minute.

Measurements of P5CS AND PDH aCtivities. The activities of P5CS and PDH were determined by the method of Shang et al. (2011). Leaf samples $(0.5 \mathrm{~g})$ were homogenized with ice-cold $50 \mathrm{~mm}$ Tris-HCl buffer ( $\mathrm{pH} 7.4$, containing $7 \mathrm{mM} \mathrm{MgCl}_{2}, 600 \mathrm{~mm}$ $\mathrm{KCl}, 3 \mathrm{~mm}$ EDTA, $1 \mathrm{~mm}$ DTT, and 5\% PVP) in a chilled mortar and pestle. The homogenate was centrifuged at 12,000 $g_{n}$ for $10 \mathrm{~min}\left(4^{\circ} \mathrm{C}\right)$ and the supernatant was collected for the determination of enzyme activity. One unit of P5CS activity was defined as the amount of enzyme required to degrade $1 \mu \mathrm{mol}$ nicotinamide adenine dinucleotide phosphate per minute. One unit of PDH activity was defined as the amount of enzyme causing a change of 0.01 in absorbance per minute at $340 \mathrm{~nm}$.

Statistical analysis. All the experiments were performed with three biological replicates, and values were given as mean \pm SD. The data were analyzed by one-way analysis of variance with the SPSS statistical software (version 13.0; IBM Corp., Armonk, NY). Significant differences were determined by Duncan's multiple range test at a level of $P<0.05$.

\section{Results}

Effect of NO ON CI IN ANThurium. When subjected to chilling stress, the CI index of anthurium plants increased with the time of treatment. However, the increased extent of CI index was effectively delayed in anthurium plants pretreated with different concentrations of $\operatorname{SNP}(0.2,0.4$, and $0.8 \mathrm{~mm})$ after $6 \mathrm{~d}$ of chilling stress, when compared with control [0 $\mathrm{mm}$ $\mathrm{SNP} \rightarrow$ Chilling (Fig. 1)]. Among them, 0.2 mM SNP pretreatment was the most effective treatment for alleviating CI in anthurium $(P<0.05)$. At the same time, the protective effect of SNP pretreatment in anthurium under chilling stress decreased with increased SNP concentration.

MDA CONTENT AND ELECTROLYTE LEAKAGE. A continuous increment of MDA content in anthurium plants was observed during chilling stress period (Fig. 2A). Samples pretreated with SNP showed a significantly lower MDA content than the control $(P<0.05)$ at different treatment times. For example, at the end of the tested chilling stress (day 15), the MDA content in $0.2 \mathrm{~mm}$ SNP pretreated samples was $11.2 \%$ lower than the control samples. The changes of electrolyte leakage shared similar trends to the MDA content. A sharp increment was observed in the control samples, but the increment was delayed by the SNP pretreatments (Fig. 2B). Moreover, it also showed that the slowest increment in electrolyte leakage came from the samples pretreated with $0.2 \mathrm{~mm}$ SNP, which was 0.56 times that of controls at the end of the chilling stress period.

Photosynthetic PigMents AND CHLOROPHYLl FLUORESCENCE. The contents of photosynthetic pigments in control plants 


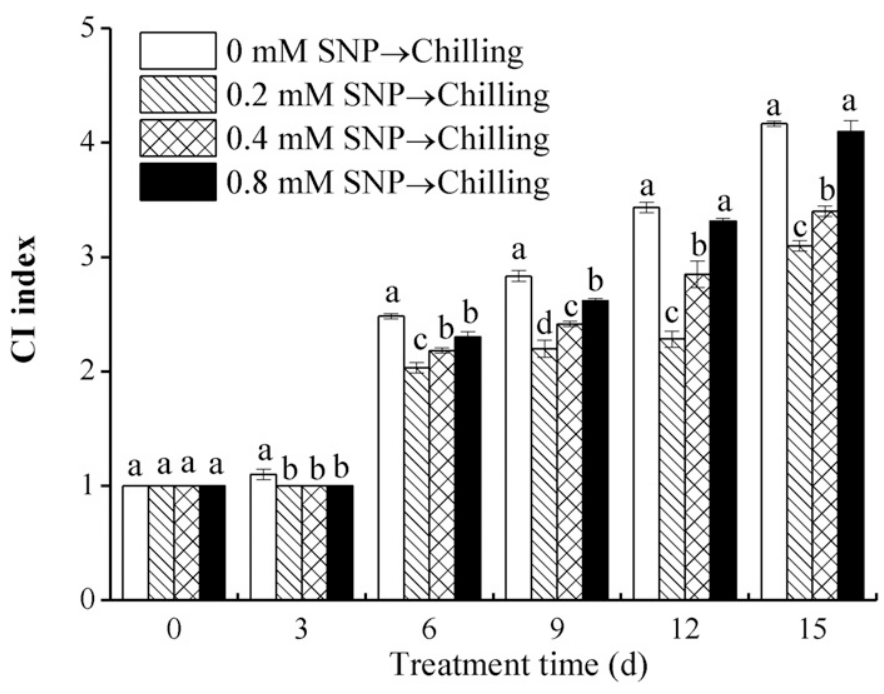

Fig. 1. Effects of nitric oxide (NO) pretreatment on the chilling injury (CI) index in anthurium under chilling stress. Anthurium plants used in this study were grown in a growth chamber for $20 \mathrm{~d}$ and then pots with established plants were sprayed with different concentrations $(0,0.2,0.4$, and $0.8 \mathrm{~mm})$ of sodium nitroprusside (SNP) three times at 2-d intervals. After that, chilling stress was performed by decreasing the temperature to $12 / 5{ }^{\circ} \mathrm{C}$ (day/night). The experiment included three biological replicates. The control $(0 \mathrm{~mm}$ $\mathrm{SNP} \rightarrow$ Chilling) was plants treated with double-distilled water. Calculation of the mean values and the SD used data from the three biological replicates. The bars show SD, whereas the different letters indicate the significant statistical differences at $P<0.05$ among the treatments according to Duncan's multiple range tests.

decreased gradually with the treatment time increasing, whereas SNP pretreatment delayed this tendency (Table 1). The decrease of photosynthetic pigment contents was mostly inhibited by $0.2 \mathrm{~mm}$ SNP pretreatment. Meanwhile, the contents of $\mathrm{Chl} a$, $\mathrm{Chl} b$, total Chl, and Car in $0.2 \mathrm{~mm}$ SNP-pretreated plants were $1.66,1.62,1.64$, and 1.61 times higher, respectively, than those of controls at day 3 . In addition, the maximum $F_{\mathrm{v}} / F_{\mathrm{m}}$ of PS II showed a similar pattern to chlorophyll content (Fig. 3). Although chilling stress resulted in a significant decrease in $F_{\mathrm{v}} / F_{\mathrm{m}}$ $(P<0.05)$, the values of $F_{\mathrm{v}} / F_{\mathrm{m}}$ in SNP-pretreated anthurium plants were still higher than those of control. Moreover, the slowest decline of $F_{\mathrm{v}} / F_{\mathrm{m}}$ was also observed in the samples when pretreated with $0.2 \mathrm{~mm}$ SNP.

$\mathrm{O}_{2}{ }^{-}$Production Rate and $\mathrm{H}_{2} \mathrm{O}_{2}$ Content. The $\mathrm{O}_{2}^{-}$production rate in all groups increased quickly during the first $9 \mathrm{~d}$ of low temperatures and then decreased progressively (Fig. 4A). Exogenous SNP pretreatment significantly inhibited the production of $\mathrm{O}_{2}^{-}$during the entire chilling treatment $(P<$ 0.05 ). The production of $\mathrm{O}_{2}^{-}$was inhibited most by $0.2 \mathrm{~mm}$ SNP pretreatment, which was $88.11 \%$ of control at $9 \mathrm{~d}$. The content of $\mathrm{H}_{2} \mathrm{O}_{2}$ increased progressively in control plants, which was evidenced by an $\approx 3.83$-fold increment within $15 \mathrm{~d}$ (Fig. 4B). The changes of $\mathrm{H}_{2} \mathrm{O}_{2}$ content in the control and SNP-pretreated anthurium plants showed the similar tendency. However, different concentrations of SNP pretreatment $(0.2,0.4$, and $0.8 \mathrm{~mm}$ ) decreased the content of $\mathrm{H}_{2} \mathrm{O}_{2}$ by $83.97 \%, 86.87 \%$, and $95.19 \%$ of control, respectively, at day 15 after chilling stress treatment.

ACTIVITIES OF ANTIOXIDANT ENZYMES AND CONTENTS OF ASA AND GSH. The changes of antioxidant enzymes, such as SOD, CAT, POD, and APX, in anthurium plants under chilling stress were shown in Fig. 5. They showed the similar change tendency
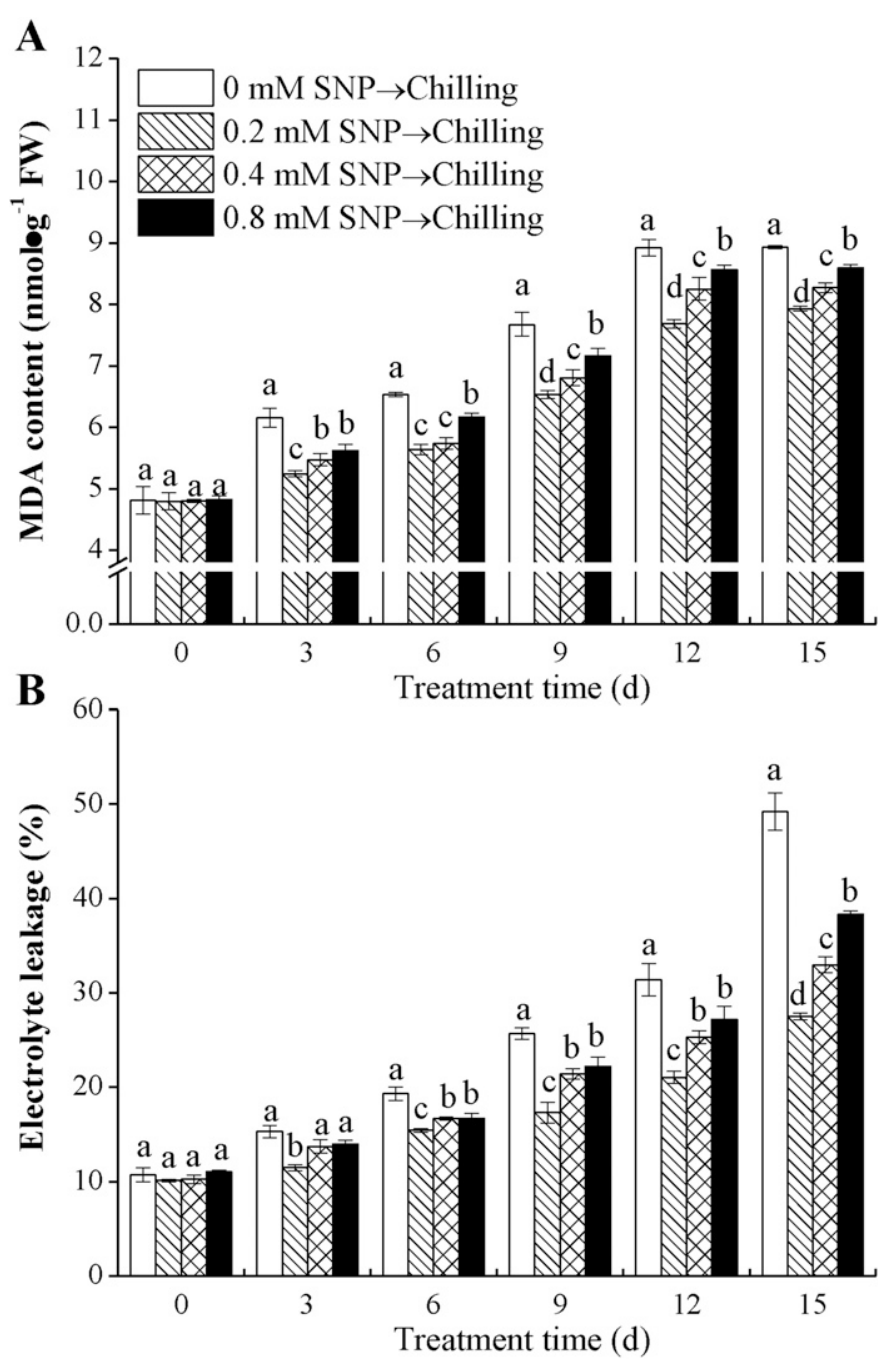

Fig. 2. Effects of nitric oxide (NO) pretreatment on (A) malondialdehyde (MDA) content and (B) electrolyte leakage in anthurium under chilling stress. Anthurium plants used in this study were grown in a growth chamber for $20 \mathrm{~d}$ and then pots with established plants were sprayed with different concentrations $(0,0.2,0.4$, and $0.8 \mathrm{~mm})$ of sodium nitroprusside (SNP) three times at 2-d intervals. After that, chilling stress was performed by decreasing the temperature to $12 / 5{ }^{\circ} \mathrm{C}$ (day/night). The experiment included three biological replicates. The control $(0 \mathrm{~mm} \mathrm{SNP} \rightarrow$ Chilling) was plants treated with double-distilled water. Calculation of the mean values and the SD used data from the three biological replicates. The bars show SD, whereas the different letters indicate the significant statistical differences at $P<0.05$ among the treatments according to Duncan's multiple range tests.

under chilling stress condition. For example, they all exhibited a significant increment after the first $6 \mathrm{~d}$ of chilling treatment; thereafter, they decreased quickly until day 15. Exogenous SNP pretreatment exhibited a positive effect on the activities of these four antioxidant enzyme activity, and the most effective SNP pretreatment concentration was $0.2 \mathrm{~mm}$.

The content of GSH in anthurium plants increased steadily during chilling stress treatment (Fig. 6A). SNP pretreatments significantly strengthened the increment of the GSH content under the stress condition. In addition, with the increasing concentration of SNP pretreatment applied, the content of GSH decreased significantly. By contrast, the content of AsA in both control and SNP-pretreated anthurium samples was steadily decreased after being treated with low temperatures (Fig. 6B). 
Table 1. Effects of nitric oxide (NO) pretreatment on the pigment content in anthurium under chilling stress. Anthurium plants used in this study were grown in a growth chamber for $20 \mathrm{~d}$, and then pots with established plants were sprayed with different concentrations $(0,0.2,0.4$, and $0.8 \mathrm{~mm}$ ) of sodium nitroprusside (SNP) three times at 2-d intervals. After that, chilling stress was performed by decreasing the temperature to $12 / 5^{\circ} \mathrm{C}$ (day/night). The experiment included three biological replicates.

\begin{tabular}{|c|c|c|c|c|c|}
\hline \multirow[b]{2}{*}{ Time (d) } & \multirow{2}{*}{$\begin{array}{c}\text { Treatment } \\
(\mathrm{mm} \rightarrow \text { Chilling })\end{array}$} & \multicolumn{4}{|c|}{ Pigment content $\left[\text { mean } \pm \mathrm{SE}\left(\mathrm{mg} \cdot \mathrm{g}^{-1} \mathrm{FW}\right)\right]^{\mathrm{z}}$} \\
\hline & & Chl $a$ & Chl $b$ & Total Chl & Car \\
\hline \multirow[t]{4}{*}{0} & 0 & $29.84 \pm 1.02 \mathrm{a}^{\mathrm{y}}$ & $16.71 \pm 0.56 \mathrm{a}$ & $46.55 \pm 1.58 \mathrm{a}$ & $8.29 \pm 0.35 \mathrm{a}$ \\
\hline & 0.2 & $29.64 \pm 1.22 \mathrm{a}$ & $16.44 \pm 0.79 \mathrm{a}$ & $46.08 \pm 2.01 \mathrm{a}$ & $8.29 \pm 0.18 \mathrm{a}$ \\
\hline & 0.4 & $29.68 \pm 1.12 \mathrm{a}$ & $15.69 \pm 0.41 \mathrm{a}$ & $45.37 \pm 1.53 \mathrm{a}$ & $8.34 \pm 0.51 \mathrm{a}$ \\
\hline & 0.8 & $29.19 \pm 0.75 \mathrm{a}$ & $15.94 \pm 0.66 \mathrm{a}$ & $45.13 \pm 1.41 \mathrm{a}$ & $8.23 \pm 0.15 \mathrm{a}$ \\
\hline \multirow[t]{4}{*}{3} & 0 & $16.31 \pm 1.08 \mathrm{~d}$ & $9.87 \pm 0.99 \mathrm{~d}$ & $26.18 \pm 2.07 \mathrm{~d}$ & $4.94 \pm 0.45 \mathrm{~d}$ \\
\hline & 0.2 & $27 \pm 1.05 \mathrm{a}$ & $16.02 \pm 0.65 \mathrm{a}$ & $43.02 \pm 1.70 \mathrm{a}$ & $7.97 \pm 0.27 \mathrm{a}$ \\
\hline & 0.4 & $24.52 \pm 1.66 \mathrm{~b}$ & $14.47 \pm 0.91 \mathrm{~b}$ & $38.99 \pm 2.57 \mathrm{~b}$ & $7.32 \pm 0.29 \mathrm{~b}$ \\
\hline & 0.8 & $21.47 \pm 0.37 \mathrm{c}$ & $12.85 \pm 0.23 \mathrm{c}$ & $34.32 \pm 0.60 \mathrm{c}$ & $6.49 \pm 0.02 \mathrm{c}$ \\
\hline \multirow[t]{4}{*}{6} & 0 & $9.64 \pm 0.10 b$ & $5.86 \pm 0.66 \mathrm{~b}$ & $15.5 \pm 0.76 \mathrm{~b}$ & $3.29 \pm 0.19 b$ \\
\hline & 0.2 & $11.37 \pm 1.00 \mathrm{a}$ & $6.98 \pm 0.07 \mathrm{a}$ & $18.35 \pm 1.07 \mathrm{a}$ & $3.87 \pm 0.27 \mathrm{a}$ \\
\hline & 0.4 & $10.08 \pm 0.71 \mathrm{~b}$ & $6.18 \pm 0.10 \mathrm{ab}$ & $16.26 \pm 0.81 \mathrm{~b}$ & $3.44 \pm 0.30 \mathrm{ab}$ \\
\hline & 0.8 & $9.76 \pm 0.22 b$ & $5.91 \pm 0.22 b$ & $15.67 \pm 0.44 \mathrm{~b}$ & $3.29 \pm 0.21 b$ \\
\hline \multirow[t]{4}{*}{9} & 0 & $8.96 \pm 0.26 \mathrm{c}$ & $5.49 \pm 0.15 b$ & $14.95 \pm 0.41 \mathrm{c}$ & $3.18 \pm 0.06 \mathrm{~b}$ \\
\hline & 0.2 & $11.19 \pm 0.12 \mathrm{a}$ & $6.79 \pm 0.62 \mathrm{a}$ & $17.98 \pm 0.74 \mathrm{a}$ & $3.75 \pm 0.26 \mathrm{a}$ \\
\hline & 0.4 & $9.34 \pm 0.07 \mathrm{~b}$ & $5.71 \pm 0.45 b$ & $15.03 \pm 0.52 \mathrm{~b}$ & $3.28 \pm 0.13 b$ \\
\hline & 0.8 & $9.32 \pm 0.19 b$ & $5.61 \pm 0.16 b$ & $14.45 \pm 0.35 b c$ & $3.24 \pm 0.11 \mathrm{~b}$ \\
\hline \multirow[t]{4}{*}{12} & 0 & $7.99 \pm 0.48 b$ & $4.84 \pm 0.24 b$ & $12.83 \pm 0.72 b$ & $2.92 \pm 0.20 \mathrm{~b}$ \\
\hline & 0.2 & $10.51 \pm 0.56 \mathrm{a}$ & $6.50 \pm 0.40 \mathrm{a}$ & $17.01 \pm 0.96 \mathrm{a}$ & $3.63 \pm 0.15 \mathrm{a}$ \\
\hline & 0.4 & $8.88 \pm 1.03 \mathrm{~b}$ & $5.45 \pm 0.64 b$ & $14.33 \pm 1.67 \mathrm{~b}$ & $3.19 \pm 0.23 b$ \\
\hline & 0.8 & $8.76 \pm 0.23 b$ & $5.31 \pm 0.40 \mathrm{~b}$ & $14.07 \pm 0.63 \mathrm{~b}$ & $3.12 \pm 0.08 \mathrm{~b}$ \\
\hline \multirow[t]{4}{*}{15} & 0 & $5.75 \pm 0.60 \mathrm{c}$ & $3.56 \pm 0.32 \mathrm{c}$ & $9.31 \pm 0.92 \mathrm{c}$ & $2.23 \pm 0.16 b$ \\
\hline & 0.2 & $10.24 \pm 0.34 \mathrm{a}$ & $7.10 \pm 0.55 \mathrm{a}$ & $18.34 \pm 0.89 \mathrm{a}$ & $3.21 \pm 0.29 \mathrm{a}$ \\
\hline & 0.4 & $8.59 \pm 0.72 b$ & $5.34 \pm 0.06 b$ & $13.93 \pm 0.78 b$ & $2.94 \pm 0.28 \mathrm{a}$ \\
\hline & 0.8 & $8.08 \pm 0.37 b c$ & $5.07 \pm 0.42 b$ & $13.15 \pm 0.79 \mathrm{~b}$ & $2.87 \pm 0.05 \mathrm{a}$ \\
\hline
\end{tabular}

${ }^{\mathrm{z}} \mathrm{Chl} a=$ chlorophyll $a$; Chl $b=$ chlorophyll $b$; Total $\mathrm{Chl}=$ total chlorophyll; Car = carotenoids; FW = fresh weight.

${ }^{\mathrm{y}}$ Numbers in a column not followed by the same letter for the same chilling stress treatment time are statistically different using Duncan's multiple range test at $P<0.05$.

However, SNP pretreatment delayed this tendency, and the content of AsA showed a significant increment in $0.2 \mathrm{~mm}$ SNPpretreated sample when compared with the control.

Total phenol content and aCtivities of PAL and PPO. The content of total phenols was found to reach a peak after $3 \mathrm{~d}$ under chilling treatment, and then decreased (Fig. 7A). During the chilling treatment time, the content of total phenols was higher in SNP-pretreated samples than in controls. The increase in total phenol content was greatest in the pretreatment with $0.2 \mathrm{~mm}$ SNP. After $3 \mathrm{~d}$ of chilling stress, the content of total phenols in $0.2 \mathrm{~mm}$ SNP-pretreated plants was 1.79 times higher than that of control plants. SNP pretreatments induced the activities of PPO and PAL enzymes, which showed an initial increase followed by a decline (Fig. 7B and C). PPO activity peaked at $6 \mathrm{~d}$ in all groups. PAL activity peaked at $3 \mathrm{~d}$ in $0.2 \mathrm{~mm}$ SNP pretreatment, whereas this activity reached the highest level at $6 \mathrm{~d}$ in other groups. PPO in anthurium pretreated with $0.2 \mathrm{~mm}$ SNP showed lower levels than control plants during the whole treatment time. However, PAL in anthurium pretreated with $0.2 \mathrm{~mm}$ SNP showed higher levels than control plants during the whole treatment.

Content OF PRoline ANd ACTIVITIES OF PDH AND P5CS. The content of proline increased steadily during the duration of the chilling stress treatment (Fig. 8A). SNP pretreatments enhanced the increase in proline, and the contents were respectively $2.17,1.58$, and 1.51 times higher than that of control plants after $15 \mathrm{~d}$ of chilling stress treatment.
Simultaneously, PDH activity was decreased in all plants during the chilling stress treatment (Fig. 8B). The activities of P5CS increased sharply first, reaching a peak on day 6 , and then decreased to the end of the treatment (Fig. 8C). In all, exogenous SNP pretreatment decreased the activity of PDH, but enhanced the activity of P5CS, with chilling stress.

\section{Discussion}

As a plant signaling molecule, NO plays an important role in the regulation of many kinds of plant processes, especially in abiotic stresses (Sheokand and Kumari, 2015; Wink and Mitchell, 1998). However, little scientific information of NO involved in CI tolerance in anthurium has been shown so far. As a common NO donor, SNP has been widely performed to play protective effect in different plants under various abiotic stresses, ranging from $5 \mu \mathrm{M}$ to $1 \mathrm{~mm}$, and showing a dosedependent manner in most cases (Leung, 2015). For example, $0.2 \mathrm{~mm}$ SNP treatment enhanced wheat seeding growth and kept high relative water content and alleviated the oxidative damage under drought conditions (Tian and Lei, 2007). In the present study, we determined that different concentrations of SNP pretreatment reduced the CI symptoms of anthurium in a dose-dependent manner under the chilling stress condition. Among them, $0.2 \mathrm{~mm}$ SNP pretreatment showed the most significant effect (Fig. 1). In addition, NO also reveals prooxidative cytotoxic property at its higher concentration. The 


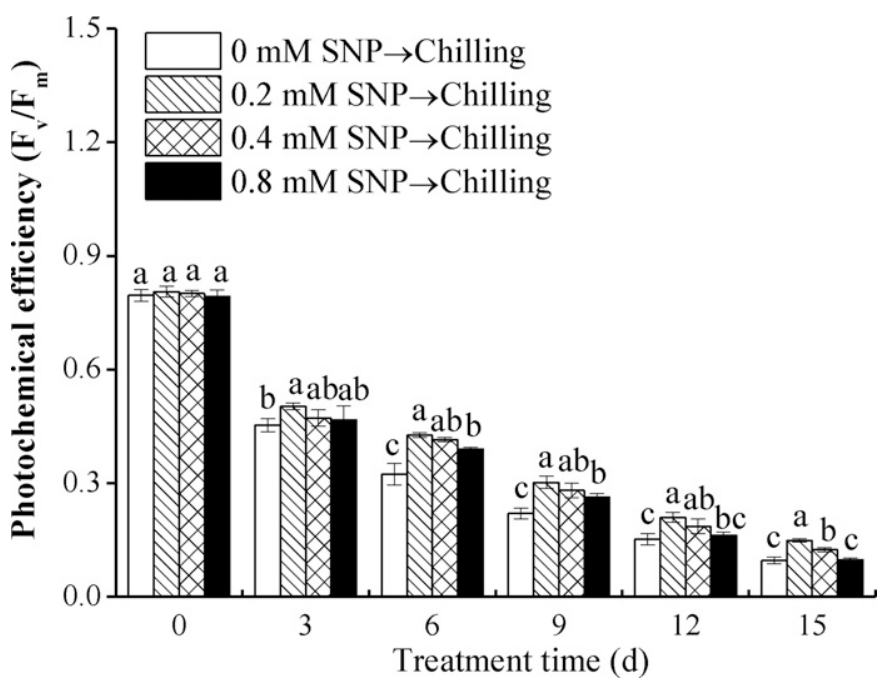

Fig. 3. Effects of nitric oxide (NO) pretreatment on photochemical efficiency $\left(F_{\mathrm{v}} / F_{\mathrm{m}}\right)$ in anthurium under chilling stress. Anthurium plants used in this study were grown in a growth chamber for $20 \mathrm{~d}$ and then pots with established plants were sprayed with different concentrations $(0,0.2,0.4$, and $0.8 \mathrm{~mm})$ of sodium nitroprusside (SNP) three times at 2-d intervals. After that, chilling stress was performed by decreasing the temperature to $12 / 5{ }^{\circ} \mathrm{C}$ (day/night). The experiment included three biological replicates. The control $(0 \mathrm{~mm}$ $\mathrm{SNP} \rightarrow$ Chilling) was plants treated with double-distilled water. Calculation of the mean values and the SD used data from the three biological replicates. The bars show SD, whereas the different letters indicate the significant statistical differences at $P<0.05$ among the treatments according to Duncan's multiple range tests.

excess of $\mathrm{NO}$ is able to inhibit plant growth and division (Corpas et al., 2011). Considering the highest $\mathrm{NO}^{+}$concentration $(6 \mu \mathrm{M})$ was recorded by the electrochemical method $2 \mathrm{~h}$ after constant illumination $\left(120 \mu \mathrm{mol} \cdot \mathrm{m}^{-2} \cdot \mathrm{s}^{-1}\right)$ in $0.2 \mathrm{~mm}$ SNP solution (Ederli et al., 2009; Floryszak-Wieczorek et al., 2006), the detailed effects of NO released by its donor should be further illuminated in anthurium.

CI leads to the structural damage to cell, such as loss of cell membrane integrity, cell membrane permeability, or relative electrolyte leakage (Aghdam and Bodbodak, 2013; Cao et al., 2012). The increase in electrolyte leakage from plant tissue exposed to chilling temperatures has been widely used as an important qualitative indicator of oxidative damage on membranes during chilling stress (Marangoni et al., 1996; Zhang et al., 2013). Besides, MDA as the final product of lipid peroxidation is also often considered as an index of cell membrane damage under environmental stress (Hodges et al., 1999; Marangoni et al., 1996). The dysfunction of one or more cell membranes may be the primary cause of CI. In this study, it was observed that the MDA content and electrolyte leakage of anthurium seedlings were increased during chilling stress, whereas different concentrations of SNP pretreatments significantly decreased the cellular damage compared with the control treatment $\left[0 \mu_{\mathrm{M}} \mathrm{SNP} \rightarrow\right.$ Chilling (Fig. 2)]. This result suggested that NO might influence membrane oxidation to enable plants to adapt to chilling stress. Previously, the protective effect of $\mathrm{NO}$ on cell membrane under different abiotic stresses has also been found (Fan et al., 2014; Farooq et al., 2009). Moreover, the photosynthesis of plants is closely associated with lipid peroxidation and ROS production (Hung et al., 2002). It has been reported that the damage to the chloroplast membrane done by low temperatures can decrease
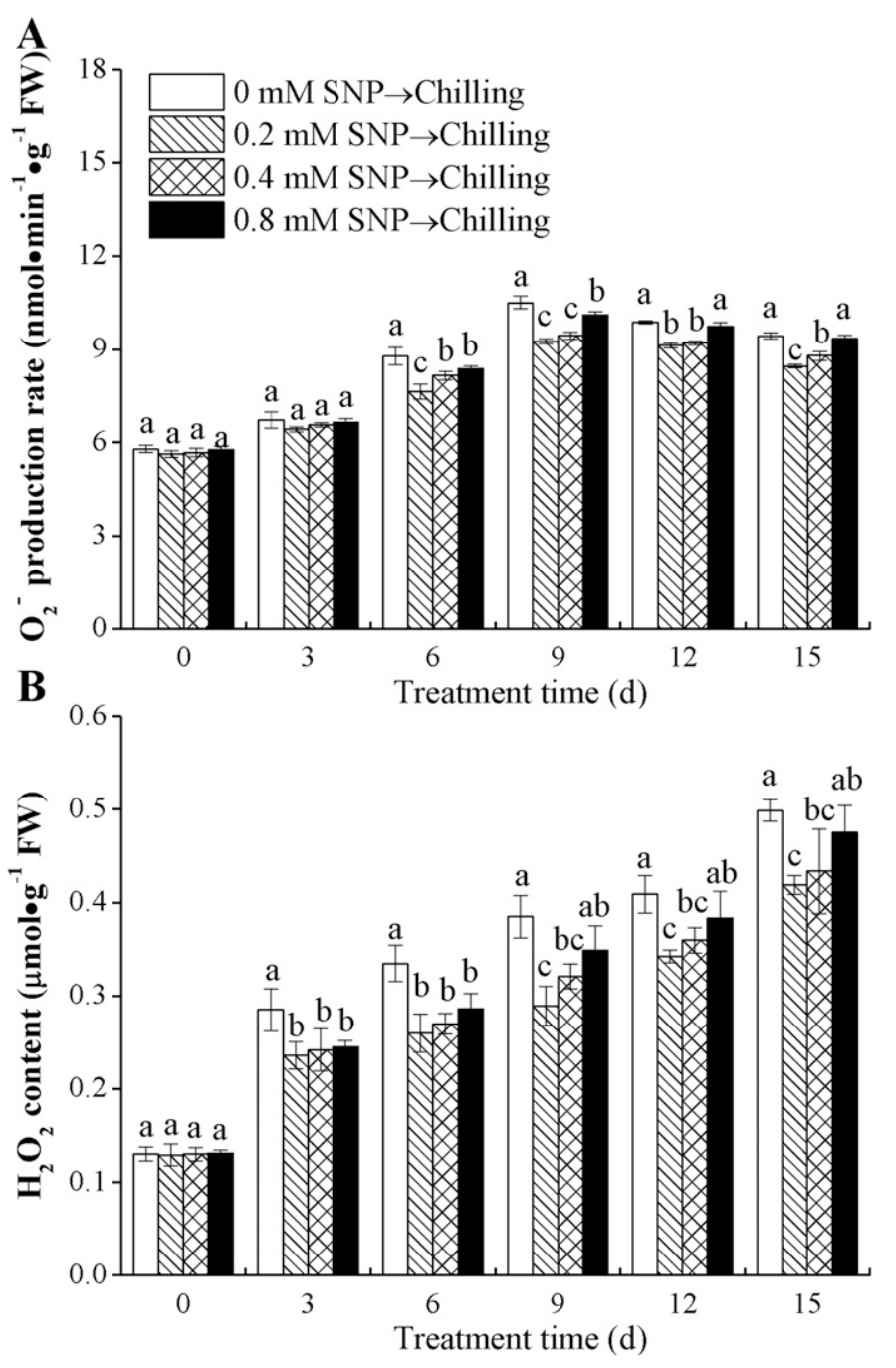

Fig. 4. Effects of nitric oxide (NO) pretreatment on (A) $\mathrm{O}_{2}^{-}$production rate and (B) $\mathrm{H}_{2} \mathrm{O}_{2}$ content in anthurium under chilling stress. Anthurium plants used in this study were grown in a growth chamber for $20 \mathrm{~d}$ and then pots with established plants were sprayed with different concentrations $(0,0.2,0.4$, and $0.8 \mathrm{~mm}$ ) of sodium nitroprusside (SNP) three times at 2-d intervals. After that, chilling stress was performed by decreasing the temperature to $12 / 5^{\circ} \mathrm{C}$ (day/ night). The experiment included three biological replicates. The control $(0 \mathrm{~mm}$ $\mathrm{SNP} \rightarrow$ Chilling) was plants treated with double-distilled water. Calculation of the mean values and the SD used data from the three biological replicates. The bars show SD, whereas the different letters indicate the significant statistical differences at $P<0.05$ among the treatments according to Duncan's multiple range tests. FW refers to fresh weight.

chlorophyll content, reduce the efficiency of PS II, and inhibit photosynthesis (Fedina et al., 1993). In the present study, the decrease in photosynthetic pigment contents (Table 1) and $F_{\mathrm{v}} / F_{\mathrm{m}}$ (Fig. 3) of PS II in anthurium was significantly postponed by exogenous SNP pretreatments. This could be due to the NO application which reduces damage to the chloroplast membrane, leading to photosynthetic efficiency being maintained under low temperature conditions.

The imbalances in metabolic processes occurring in abiotic stresses including CI may lead to an increased accumulation of ROS, such as $\mathrm{O}_{2}^{-}$and $\mathrm{H}_{2} \mathrm{O}_{2}$ (Ruelland et al., 2009). Antioxidant enzymes, such as SOD, POD, CAT, and APX, establish one of the most important parts of the ROS scavenging system in plant cells, which can reduce the toxicity caused by the production of 
A
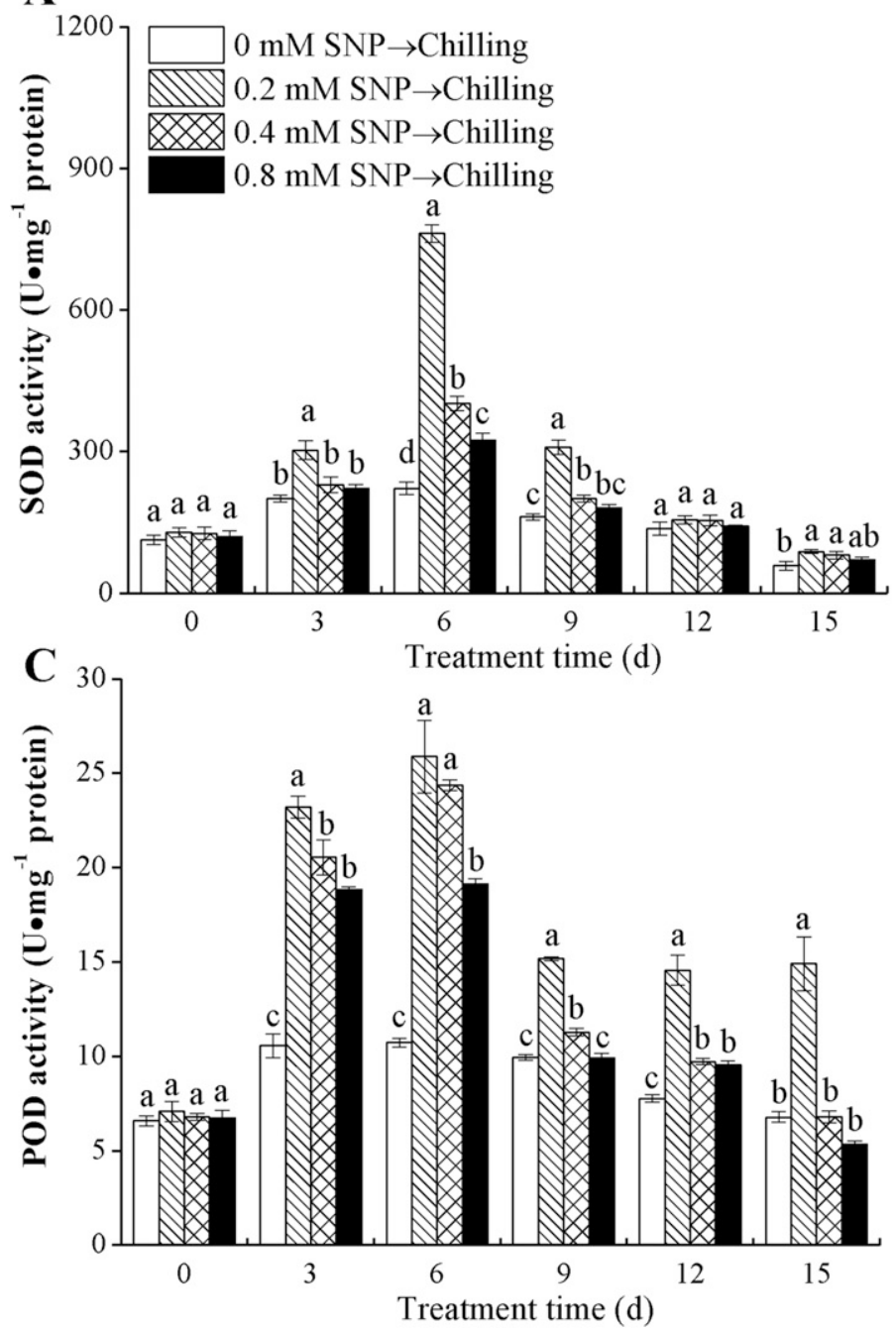

B
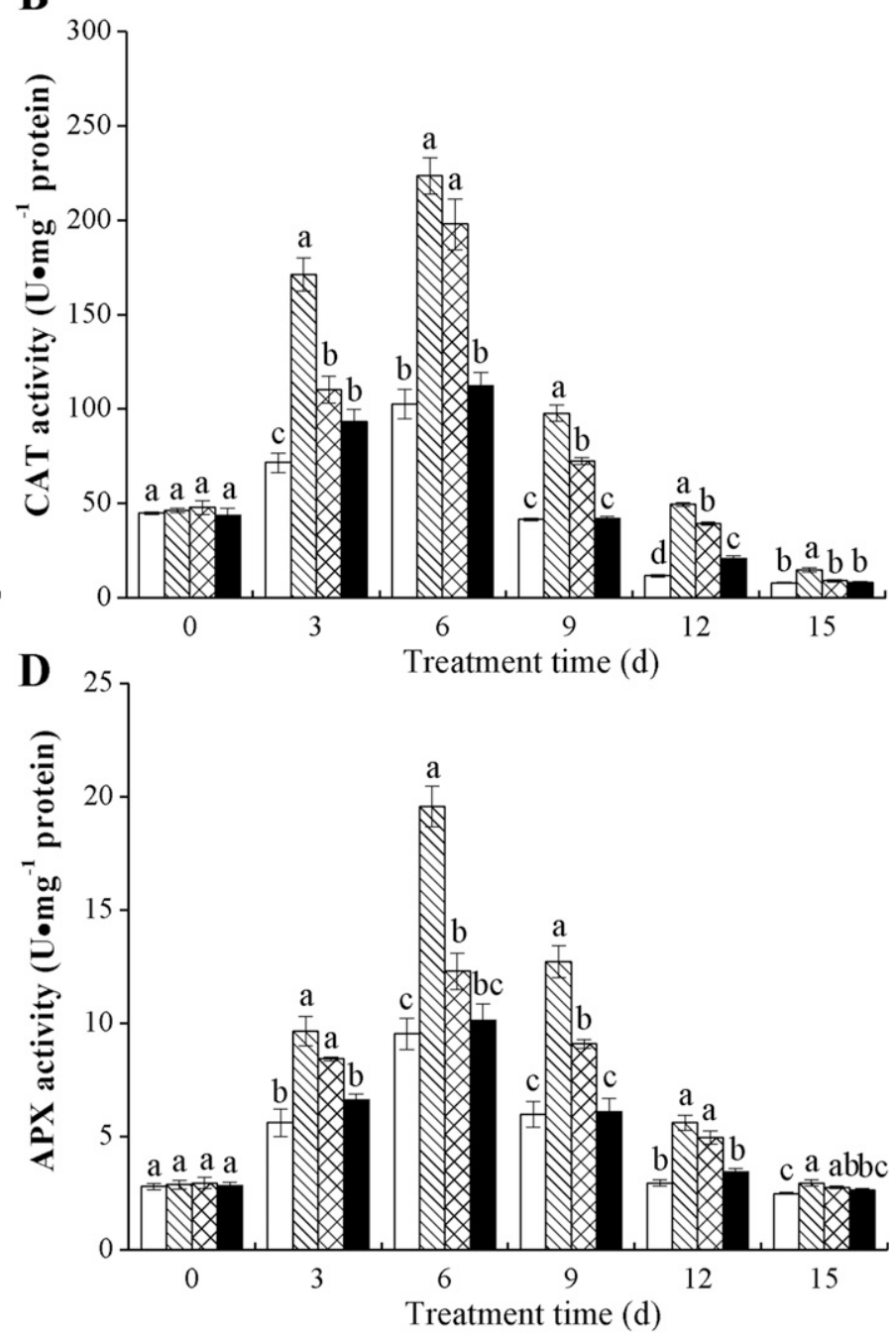

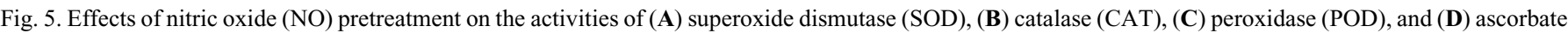
peroxidase (APX) in anthurium under chilling stress. Anthurium plants used in this study were grown in a growth chamber for $20 \mathrm{~d}$ and then pots with established plants were sprayed with different concentrations $(0,0.2,0.4$, and $0.8 \mathrm{~mm})$ of sodium nitroprusside (SNP) three times at 2 -d intervals. After that, chilling stress was performed by decreasing the temperature to $12 / 5^{\circ} \mathrm{C}$ (day/night). The experiment included three biological replicates. The control ( 0 mM SNP $\rightarrow \mathrm{Chilling}$ ) was plants treated with double-distilled water. Calculation of the mean values and the SD used data from the three biological replicates. The bars show SD, whereas the different letters indicate the significant statistical differences at $P<0.05$ among the treatments according to Duncan's multiple range tests.

$\mathrm{O}_{2}^{-}$and $\mathrm{H}_{2} \mathrm{O}_{2}$ (Zhang et al., 2009; Zhou et al., 2006). Meanwhile, antioxidant enzymes have also been demonstrated to be important factors for plant tolerance to various environmental stresses (Wang et al., 2010). Many studies have confirmed that NO can improve plant tolerance to abiotic stresses by acting as a direct ROS scavenger or modulating components of antioxidative system (Sheokand and Kumari, 2015). For example, NO could serve as an antioxidant during several stress to interact with ROS in various ways, directly scavenging ROS, such as $\mathrm{O}_{2}^{-}$to form peroxynitrite $\left(\mathrm{ONOO}^{-}\right)$ (Misra et al., 2011), comparatively less toxic than peroxides and thus restricts the cellular damage in plants. Moreover, NO also functions as a signaling molecule to maintain the cellular homeostasis and regulates the toxicity of ROS by its augmentation of antioxidant content and antioxidative enzyme activity, which affects cell wall components and regulates the expression of stress-related genes (Sheokand and Kumari, 2015). Here, our results clearly showed that the application of SNP pretreatment could markedly decrease the rate of $\mathrm{O}_{2}^{-}$production and content of $\mathrm{H}_{2} \mathrm{O}_{2}$ under chilling stress (Fig. 4). Meanwhile, the increased activities of SOD, POD, CAT, and APX were also observed by pretreatment with SNP (Fig. 5). Similar results were also observed previously (Chongchatuporn et al., 2013; Sheokand et al., 2010).

In addition to antioxidant enzymes, nonenzymatic antioxidants also play critical roles in scavenging ROS in plants subjected to chilling conditions. For instance, GSH and AsA play key roles in reducing ROS levels in plants (Agastian et al., 2000). NO treatment has been shown to enhance GSH and AsA contents and increase the activities of antioxidant enzymes, while alleviating the production of $\mathrm{H}_{2} \mathrm{O}_{2}$ and $\mathrm{O}_{2}^{-}$(Chen et al., 2014). Moreover, in the presence of $\mathrm{O}_{2}, \mathrm{NO}$ can react with GSH to form $S$-nitrosoglutathione (GSNO), a reactive nitrogen form, which is also a long-distance signaling molecule and a natural reservoir of NO (Airaki et al., 2012). In our study, higher AsA and GSH contents were also observed in SNP-pretreated anthurium plants 

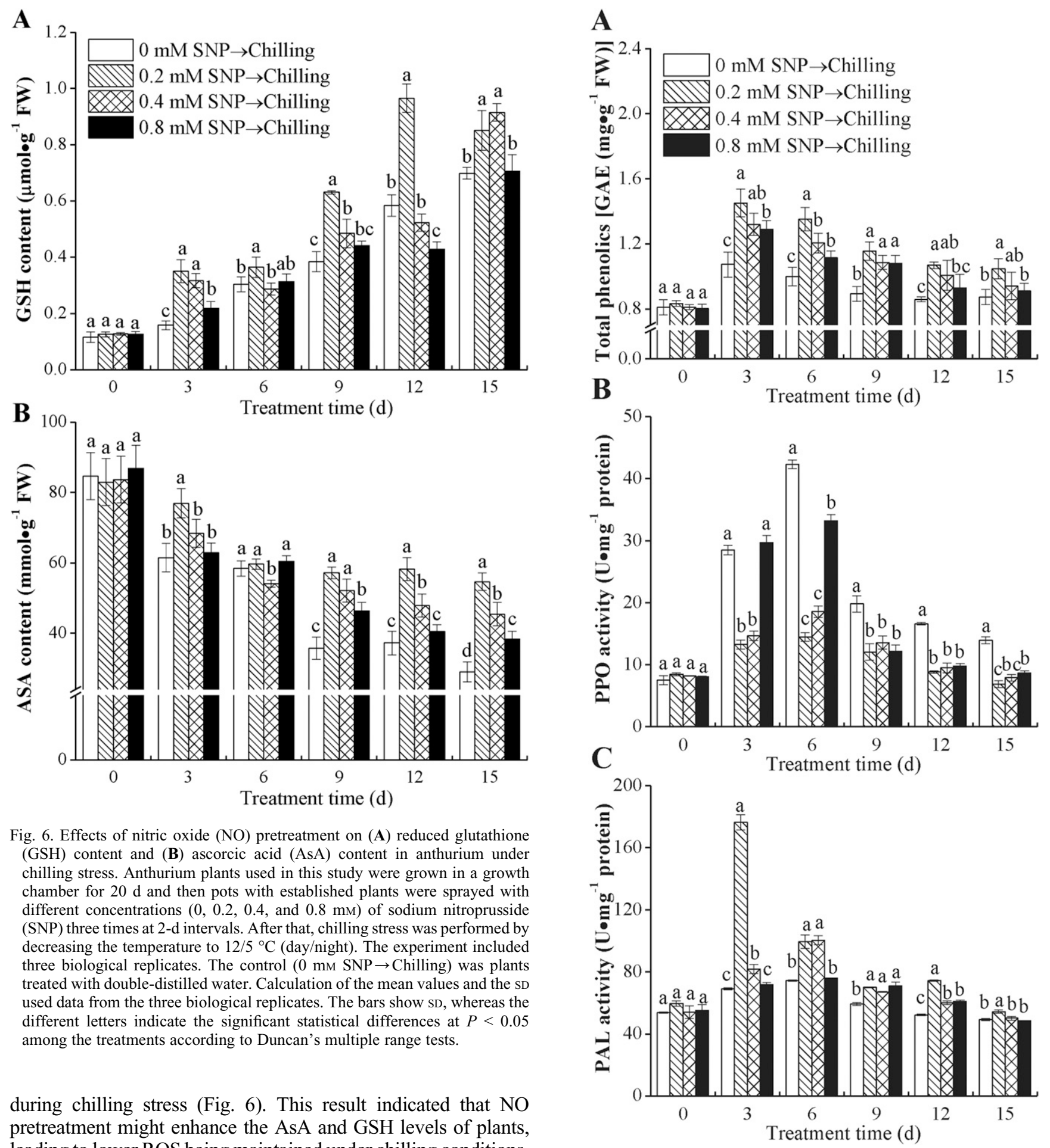

Fig. 6. Effects of nitric oxide (NO) pretreatment on (A) reduced glutathione (GSH) content and (B) ascorcic acid (AsA) content in anthurium under chilling stress. Anthurium plants used in this study were grown in a growth chamber for $20 \mathrm{~d}$ and then pots with established plants were sprayed with different concentrations $(0,0.2,0.4$, and $0.8 \mathrm{~mm})$ of sodium nitroprusside (SNP) three times at 2-d intervals. After that, chilling stress was performed by decreasing the temperature to $12 / 5{ }^{\circ} \mathrm{C}$ (day/night). The experiment included three biological replicates. The control $(0 \mathrm{~mm}$ SNP $\rightarrow$ Chilling $)$ was plants treated with double-distilled water. Calculation of the mean values and the SD used data from the three biological replicates. The bars show SD, whereas the different letters indicate the significant statistical differences at $P<0.05$ among the treatments according to Duncan's multiple range tests.

during chilling stress (Fig. 6). This result indicated that NO pretreatment might enhance the AsA and GSH levels of plants, leading to lower ROS being maintained under chilling conditions. Besides, stress conditions often result in a much more phenolic production, which can be used to inhibit the initiation or propagation of oxidizing chain reactions and thus alleviate chilling damage (Pennycooke et al., 2005). PAL and PPO are two key enzymes in the synthesis and decomposition of phenolics and have been reported to protect plants against stress conditions by regulating phenolic products (Dixon and Paiva, 1995; Mayer, 2006). It has been reported that MJ and SA treatment could alleviate chilling damage in lemon (Citrus limon) fruit by increasing the synthesis of total phenolics and PAL while inhibiting the activity of PPO (Siboza et al., 2014). In the present

Fig. 7. Effects of nitric oxide (NO) pretreatment on (A) total phenolics content, (B) polphenol oxidase (PPO) activity, and (C) phenylalanine ammonialyase (PAL) activity in anthurium under chilling stress. Anthurium plants used in this study were grown in a growth chamber for $20 \mathrm{~d}$ and then pots with established plants were sprayed with different concentrations $(0,0.2,0.4$, and $0.8 \mathrm{~mm}$ ) of sodium nitroprusside (SNP) three times at 2-d intervals. After that, chilling stress was performed by decreasing the temperature to $12 / 5^{\circ} \mathrm{C}$ (day/ night). The experiment included three biological replicates. The control $(0 \mathrm{~mm}$ $\mathrm{SNP} \rightarrow$ Chilling) was plants treated with double-distilled water. Calculation of the mean values and the SD used data from the three biological replicates. The bars show SD, whereas the different letters indicate the significant statistical differences at $P<0.05$ among the treatments according to Duncan's multiple range tests. 

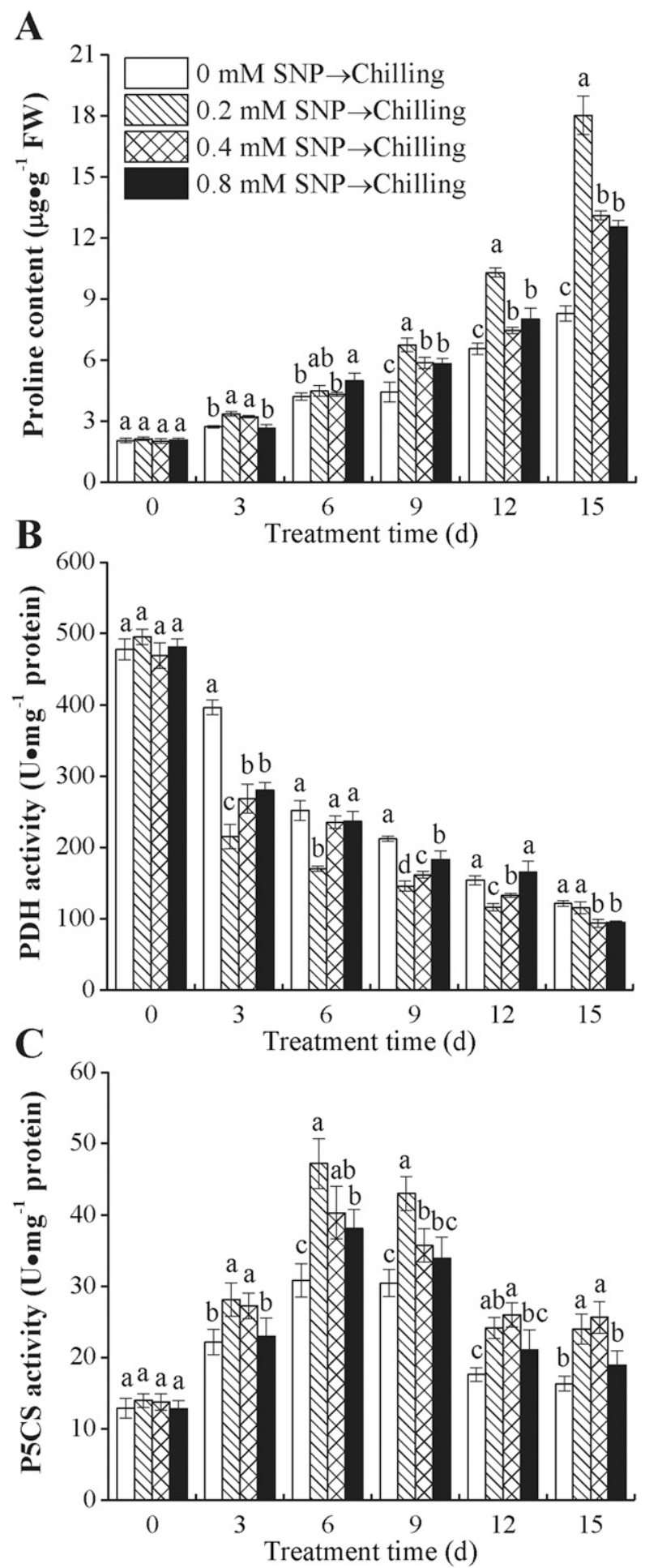

Fig. 8. Effects of nitric oxide (NO) pretreatment on (A) proline content, (B) proline dehydrogenase (PDH) activity, and (C) $\Delta 1$-pyrroline-5-carboxylate synthetase (P5CS) activity in anthurium under chilling stress. Anthurium plants used in this study were grown in a growth chamber for $20 \mathrm{~d}$, and then pots with established plants were sprayed with different concentrations $(0,0.2,0.4$, and $0.8 \mathrm{~mm})$ of sodium nitroprusside (SNP) three times at 2-d intervals. After that, chilling stress was performed by decreasing the temperature to $12 / 5^{\circ} \mathrm{C}$ (day/night). The experiment included three biological replicates. The control ( $0 \mathrm{~mm}$ SNP $\rightarrow$ Chilling) was plants treated with doubledistilled water. Calculation of the mean values and the SD used data from the three biological replicates. The bars show SD, whereas the different letters indicate the significant statistical differences at $P<0.05$ among the treatments according to Duncan's multiple range tests. study, higher total phenolic contents and PAL activity, with lower PPO activity were observed in SNP-pretreated anthurium plants (Fig. 7). This result suggested that the application of exogenous NO could enhance the chilling tolerance of anthurium by affecting the phenolic metabolism.

It was proposed that NO induction under cold stress played a role in freezing tolerance through proline synthesis (Zhao et al., 2009). As one of the osmotic regulators, proline also plays a pivotal role in protecting plant cells against abiotic stresses (Li et al., 2013). For example, proline plays important physiological roles in osmotic adjustment, regulation of the $\mathrm{NAD}^{+} / \mathrm{NADH}$ ratio, stabilizing membrane structures, and scavenging ROS (Ashraf and Harris, 2004). Although the actual role of proline accumulation remains unclear, it has been indicated that proline may enhance plants stress tolerance by adjusting cellular osmosis, balancing the redox status of the cell, modifying the activity of antioxidant enzymes, eliminating ROS, and stabilizing the structure of biological macromolecules (Ben Ahmed et al., 2010; Iqbal et al., 2014; Ozden et al., 2009). In addition, the accumulation of proline is a phenomenon frequently occurring in plants under environmental stresses (Ashraf and Foolad, 2007; Szabados and Savouré, 2010). Moreover, some reports have shown that proline also seems to be involved in signal transduction pathways that regulate stress-responsive adaptive responses (Lehmann et al., 2010; Maggio et al., 2002). On the other hand, proline accumulation is also a complex, dynamic process, in which P5CS and PDH play decisive roles (Ruiz et al., 2002; Verbruggen and Hermans, 2008). During chilling stress, the accumulation of proline in plants is part of the defense response against CI (Shang et al., 2011). The application of exogenous SNP also protects plants from abiotic stress by boosting the contents of proline (Farooq et al., 2009). Our results showed a significant increase in proline contents with pretreatment of SNP after chilling stress (Fig. 8A). Meanwhile, the increased proline contents were associated with lower PDH activity (Fig. 8B) and higher P5CS activity (Fig. 8C), which is similar to the results reported before (Cao et al., 2012). These results indicated that NO pretreatment might enhance the chilling tolerance of anthurium by mediating proline metabolism.

In conclusion, our results suggest that NO could increase chilling tolerance in anthurium by stimulating the antioxidant defense system, decreasing the accumulation of ROS, and elevating antioxidant contents. These acquired results explain the beneficial role of NO in improving chilling tolerance in anthurium and will also provide in-depth information on different strategies which NO adopts in facing the detrimental effects of abiotic stress.

\section{Literature Cited}

Agastian, P., S.J. Kingsley, and M. Vivekanandan. 2000. Effect of salinity on photosynthesis and biochemical characteristics in mulberry genotypes. Photosynthetica 38:287-290.

Aghdam, M.S. and S. Bodbodak. 2013. Physiological and biochemical mechanisms regulating chilling tolerance in fruits and vegetables under postharvest salicylates and jasmonates treatments. Scientia Hort. 156:73-85.

Aghdam, M.S., L. Sevillano, F.B. Flores, and S. Bodbodak. 2013. Heat shock proteins as biochemical markers for postharvest chilling stress in fruits and vegetables. Scientia Hort. 160:54-64.

Aghdam, M.S., R. Naderi, M.A.A. Sarcheshmeh, and M. Babalar. 2015. Amelioration of postharvest chilling injury in anthurium cut flowers by $\gamma$-aminobutyric acid (GABA) treatments. Postharvest Biol. Technol. 110:70-76. 
Airaki, M., M. Leterrier, R.M. Mateos, R. Valderrama, M. Chaki, J.B. Barroso, L.A. Del Río, J.M. Palma, and F.J. Corpas. 2012. Metabolism of reactive oxygen species and reactive nitrogen species in pepper (Capsicum annuum L.) plants under low temperature stress. Plant Cell Environ. 35:281-295.

Ashraf, M. and M.R. Foolad. 2007. Roles of glycinebetaine and proline in improving plant abiotic stress resistance. Environ. Expt. Bot. 59:206-216.

Ashraf, M. and P.J.C. Harris. 2004. Potential biochemical indicators of salinity tolerance in plants. Plant Sci. 166:3-16.

Ben Ahmed, C., S. Magdich, B. Ben Rouina, S. Sensoy, M. Boukhris, and F. Ben Abdullah. 2010. Exogenous proline effects on water relations and ions contents in leaves and roots of young olive. Amino Acids 40:565-573.

Beyer, W.F. and I. Fridovich. 1987. Assaying for superoxide dismutase activity: Some large consequences of minor changes in conditions. Anal. Biochem. 161:559-566.

Blokhina, O., E. Virolainen, and K.V. Fagerstedt. 2003. Antioxidants, oxidative damage and oxygen deprivation stress: A review. Ann. Bot. 91:179-194.

Bradford, M.M. 1976. A rapid and sensitive method for the quantitation of microgram quantities of protein utilizing the principle of protein dye binding. Anal. Biochem. 72:248-254.

Cao, S.F., Y.T. Cai, Z.F. Yang, and Y.H. Zheng. 2012. MeJA induces chilling tolerance in loquat fruit by regulating prolineand $\gamma$-aminobutyric acid contents. Food Chem. 133:1466-1470.

Chen, J., Q. Xiao, C. Wang, W.H. Wang, F.H. Wu, J. Chen, B.Y. He, Z. Zhu, Q.M. Ru, L.L. Zhang, and H.L. Zhang. 2014. Nitric oxide alleviates oxidative stress caused by salt in leaves of a mangrove species, Aegiceras corniculatum. Aquat. Bot. 117:41-47.

Chen, J.Y., L.H. He, Y.M. Jiang, Y. Wang, D.C. Joyce, Z.L. Ji, and W.J. Lu. 2008. Role of phenylalanine ammonia-lyase in heat pretreatment-induced chilling tolerance in banana fruit. Physiol. Plant. 132:318-328.

Chongchatuporn, U., S. Ketsa, and W.G. van Doorn. 2013. Chilling injury in mango (Mangifera indica) fruit peel: Relationship with ascorbic acid concentrations and antioxidant enzyme activities. Postharvest Biol. Technol. 86:409-417.

Corpas, F.J., M. Leterrier, R. Valderrama, M. Airaki, M. Chaki, J.M. Palma, and J.B. Barroso. 2011. Nitric oxide imbalance provokes a nitrosative response in plants under abiotic stress. Plant Sci. 181:604-611.

Dixon, R.A. and N.L. Paiva. 1995. Stress-induced phenylpropanoid metabolism. Plant Cell 7:1085-1097.

Ederli, L., L. Reale, L. Madeo, F. Ferranti, C. Gehring, M. Fornaciari, B. Romano, and S. Pasqualini. 2009. NO release by nitric oxide donors in vitro and in planta. Plant Physiol. Biochem. 47:42-48.

Fan, H., C. Du, Y. Xu, and X. Wu. 2014. Exogenous nitric oxide improves chilling tolerance of chinese cabbage seedlings by affecting antioxidant enzymes in leaves. Hort. Environ. Biotechnol. 55:159-165. Farooq, M., S.M.A. Basra, A. Wahid, and H. Rehman. 2009. Exogenously applied nitric oxide enhances the drought tolerance in fine grain aromatic rice (Oryza sativa L.). J. Agron. Crop Sci. 195:254-261.

Fedina, I.S., T.S. Tsonev, and E.I. Guleva. 1993. The effect of pretreatment with proline on the responses of Pisum sativum to salt stress. Photosynthetica 29:521-527.

Ferguson, I.B., C.B. Watkins, and J.E. Harman. 1983. Inhibition by calcium of senescence of detached cucumber cotyledons: Effect on ethylene and hydroperoxide production. Plant Physiol. 71:182-186.

Floryszak-Wieczorek, J., G. Milczarek, M. Arasimowicz, and A. Ciszewski. 2006. Do nitric oxide donors mimic endogenous NOrelated response in plants? Planta 224:1363-1372.

Gantait, S. and N. Mandal. 2010. Tissue culture of Anthurium andraeanum: A significant review and future prospective. Intl. J. Bot. 6:207-219.

Hodges, D.M., J.M. DeLong, C.F. Forney, and R.K. Prange. 1999. Improving the thiobarbituric acid-reactive-substances assay for estimating lipid peroxidation in plant tissues containing anthocyanin and other interfering compounds. Planta 207:604-611.

Hossain, M.A., M. Hasanuzzaman, and M. Fujita. 2010. Up-regulation of antioxidant and glyoxalase systems by exogenous glycinebetaine and proline in mung bean confer tolerance to cadmium stress. Physiol. Mol. Biol. Plants 16:259-272.

Hung, K.T., C.J. Chang, and C.H. Kao. 2002. Paraquat toxicity is reduced by nitric oxide in rice leaves. J. Plant Physiol. 159:159-166.

Iqbal, N., S. Umar, N.A. Khan, and M.I.R. Khan. 2014. A new perspective of phytohormones in salinity tolerance: Regulation of proline metabolism. Environ. Expt. Bot. 100:34-42.

Javadian, N., G. Karimzadeh, S. Mahfoozi, and F. Ghanati. 2010. Cold-induced changes of enzymes, proline, carbohydrates, and chlorophyll in wheat. Russ. J. Plant Physiol. 57:540-547.

Kratsch, H.A. and R.R. Wise. 2000. The ultrastructure of chilling stress. Plant Cell Environ. 23:337-350.

Krüger, G.H.J., M. Tsimilli-Michael, and R.J. Strasser. 1997. Light stress provokes plastic and elastic modifications in structure and function of photosystem II in camellia leaves. Physiol. Plant. 101:265-277.

Lehmann, S., D. Funck, and L. Szabados. 2010. Proline metabolism and transport in plant development. Amino Acids 39:949-962.

Leung, D.W.M. 2015. Regulatory role of nitric oxide in alterations of morphological features of plants under abiotic stress, p. 65-76. In: M.N. Khan, M. Mobin, F. Mohammad, and F.J. Corpas (eds.). Nitric oxide action in abiotic stress responses in plants. Springer, Dordrecht, The Netherland.

Li, Q., Y. Lu, Y. Shi, T. Wang, K. Ni, L. Xu, S. Liu, L. Wang, Q. Xiong, and J.P. Giesy. 2013. Combined effects of cadmium and fluoranthene on germination, growth and photosynthesis of soybean seedlings. J. Environ. Sci. (China) 25:1936-1946.

Lichtenthaler, H.K. 1987. Chlorophylls and carotenoids: Pigments of photosynthetic biomembranes. Methods Enzymol. 148:350-382.

Lin, Y., Z.Z. Liu, Q.H. Shi, X.F. Wang, M. Wei, and F.J. Yang. 2012. Exogenous nitric oxide (NO) increased antioxidant capacity of cucumber hypocotyl and radicle under salt stress. Scientia Hort. 142:118-127.

Luo, Z.S., D.D. Li, R.X. Du, and W.S. Mou. 2015. Hydrogen sulfide alleviates chilling injury of banana fruit by enhanced antioxidant system and proline content. Scientia Hort. 183:144-151.

Maggio, A., S. Miyazaki, P. Veronese, T. Fujita, J.I. Ibeas, B. Damsz, M.L. Narasimhan, P.M. Hasegawa, R.J. Joly, and R.A. Bressan. 2002. Does proline accumulation play an active role in stressinduced growth reduction? Plant J. 31:699-712.

Marangoni, A.G., T. Palma, and D.W. Stanley. 1996. Membrane effects in postharvest physiology. Postharvest Biol. Technol. 7:193-217.

Mayer, A.M. 2006. Ployphenol oxidases in plants and fungi: Going places? A review. Phytochemistry 67:2318-2331.

Misra, A.N., M. Misra, and R. Singh. 2011. Nitric oxide: A ubiquitous signaling molecule with diverse role in plants. Afr. J. Plant Sci. 5:57-74.

Mur, L.A., J. Mandon, S. Persijn, S.M. Cristescu, I.E. Moshkov, G.V. Novikova, M.A. Hall, F.J. Harren, K.H. Hebelstrup, and K.J. Gupta. 2012. Nitric oxide in plants: An assessment of the current state of knowledge. AoB Plants 5:pls052.

Nakano, Y. and K. Asada. 1981. Hydrogen peroxide scavenged by ascorbate-specific peroxidase in spinach chloroplast. Plant Cell Physiol. 22:867-880.

Nguyen, T.B.T., S. Ketsa, and W.G. vanDoorn. 2003. Relationship between browning and the activities of polyphenoloxidase and phenylalanine ammonia lyase in banana peel during low temperature storage. Postharvest Biol. Technol. 30:187-193.

Ozden, M., U. Demirel, and A. Kahraman. 2009. Effects of proline on antioxidant system in leaves of grapevine (Vitis vinifera L.) exposed to oxidative stress by $\mathrm{H}_{2} \mathrm{O}_{2}$. Scientia Hort. 119:163-168.

Patra, H.L., M. Kar, and D. Mishre. 1978. Catalase activity in leaves and cotyledons during plant development and senescence. Biochem. Physiol. Pflanz. 172:385-390. 
Pennycooke, J.C., S. Cox, and C. Stushnoff. 2005. Relationship of cold acclimation, total phenolic content and antioxidant capacity with chilling tolerance in petunia (Petunia hybrida). Environ. Expt. Bot. 53:225-232.

Polle, A., T. Otter, and F. Seifert. 1994. Apoplastic peroxidases and lignification in needles of Norway spruce (Picea abies L.). Plant Physiol. 106:53-60.

Procházková, D., N. Wilhelmová, and M. PavlíK. 2015. Reactive nitrogen species and nitric oxide, p. 3-20. In: M.N. Khan, M. Mobin, F. Mohammad, and F.J. Corpas (eds.). Nitric oxide action in abiotic stress responses in plants. Springer, Dordrecht, The Netherland.

Promyou, S., S. Ketsa, and W.G.V. Doorn. 2012. Salicylic acid chilling injury in anthurium (Anthurium andraeanum L.) flowers. Postharvest Biol. Technol. 64:104-110.

Qiao, W. and L. Fan. 2008. Nitric oxide signaling in plant responses to abiotic stresses. J. Integr. Plant Biol. 50:1238-1246.

Ruelland, E., M.N. Vaultier, A. Zachowski, and V. Hurry. 2009. Cold signalling and cold acclimation in plants, p. 35-150. In: K. JeanClaude and D. Michel (eds.). Advances in botanical research, Academic Press, Burlington, MA.

Rui, H., S. Cao, H. Shang, P. Jin, K. Wang, and Y. Zheng. 2010. Effects of heat treatment on internal browing and membrane fatty acid in loquat fruit in reponse to chilling stress. J. Sci. Food Agr. 90:15571561.

Ruiz, J.M., E. Sánchez, P.C. García, L.R. López-Lefebre, R.M. Rivero, and L. Romero. 2002. Proline metabolism and NAD kinase activity in greenbean plants subjected to cold-shock. Phytochemistry 59:473-478.

Scandalios, J.G. 1993. Oxygen stress and superoxide dismutases. Plant Physiol. 101:7-12.

Shang, H.T., S.F. Cao, Z.F. Yang, Y.T. Cai, and Y.H. Zheng. 2011. Effect of exogenous $\gamma$-aminobutyric acid treatment on proline accumulation and chilling injury in peach fruit after long-term cold storage. J. Agr. Food Chem. 59:1264-1268.

Sharma, P., A.B. Jha, R.S. Dubey, and M. Pessarakli. 2012. Antioxidative defense mechanism in plants under stressful conditions. J. Bot. 2012:217037.

Sheokand, S., V. Bhankar, and V. Sawhney. 2010. Ameliorative effect of exogenous nitric oxide on oxidative metabolism in $\mathrm{NaCl}$ treated chickpea plants. Braz. J. Plant Physiol. 22:81-90.

Sheokand, S. and A. Kumari. 2015. Nitric oxide and abiotic stressinduced oxidative stress, p. 43-64. In: M.N. Khan, M. Mobin, F. Mohammad, and F.J. Corpas (eds.). Nitric oxide action in abiotic stress responses in plants. Springer, Dordrecht, The Netherland.

Siboza, X.I., I. Bertling, and A.O. Odindo. 2014. Salicylic acid and methyl jasmonate improve chilling tolerance in cold-stored lemon fruit (Citrus limon). J. Plant Physiol. 171:1722-1731.

Siddiqui, M.H., M.H. Al-Whaibi, and M.O. Basalah. 2011. Role of nitric oxide in tolerance of plants to abiotic stress. Protoplasma 248:447-455.

Singh, S.P., Z. Singh, and E.E. Swinny. 2009. Postharvest nitric oxide fumigation delays fruit ripening and alleviates chilling injury during cold storage of japanese plums (Prunus salicina Lindell). Postharvest Biol. Technol. 53:101-108.

Suzuki, N. and R. Mittler. 2006. Reactive oxygen species and temperature stresses: A delicate balance between signaling and destruction. Physiol. Plant. 126:45-51.

Szabados, L. and A. Savouré. 2010. Proline: A multifunctional amino acid. Trends Plant Sci. 15:89-97.
Tanaka, K., Y. Suda, N. Kondo, and K. Sugahara. 1985. O3 tolerance and the ascorbate-dependent $\mathrm{H}_{2} \mathrm{O}_{2}$ decomposing system in chloroplasts. Plant Cell Physiol. 26:1425-1431.

Tian, X. and Y. Lei. 2007. Physiological responses of wheat seedlings to drought and UV-B radiation. Effect of exogenous sodium nitroprusside application. Russ. J. Plant Physiol. 54:676-682.

Tian, D.Q., X.Y. Pan, Y.M. Yu, W.Y. Wang, F. Zhang, Y.Y. Ge, X.L. Shen, F.Q. Shen, and X.J. Liu. 2013. De novo characterization of the Anthurium transcriptome and analysis of its digital gene expression under cold stress. BMC Genomics 14:827.

Tsantili, E., Y. Shin, J.F. Nock, and C.B. Watkins. 2010. Antioxidant concentrations during chilling injury development in peaches. Postharvest Biol. Technol. 57:27-34.

Verbruggen, N. and C. Hermans. 2008. Proline accumulation in plants: A review. Amino Acids 35:753-759.

Venkat, S.K., P. Bommisetty, M.S. Patil, L. Reddy, and A. Chennareddy. 2014. The genetic linkage maps of Anthurium species based on RAPD, ISSR and SRAP markers. Scientia Hort. 178:132-137.

Wang, Y., J.L. Li, J.Z. Wang, and Z.K. Li. 2010. Exogenous $\mathrm{H}_{2} \mathrm{O}_{2}$ improves the chilling tolerance of manilagrass and mascarenegrass by activating the antioxidative system. Plant Growth Regulat. 61:195-204.

Wang, Y.S., Z.S. Luo, R.X. Du, Y. Liu, T.J. Ying, and L.C. Mao. 2013. Effect of nitric oxide on antioxidative response and proline metabolism in banana during cold storage. J. Agr. Food Chem. 61:8880-8887.

Wink, D.A. and J.B. Mitchell. 1998. Chemical biology of nitric oxide: Insights into regulatory, cytotoxic, and cytoprotective mechanisms of nitric oxide. Free Radic. Biol. Med. 25:434-456.

Wu, B., Q. Guo, Q.P. Li, Y.M. Ha, X.P. Li, and W.X. Chen. 2014. Impact of postharvest nitric oxide treatment on antioxidant enzymes and related genes in banana fruit in response to chilling tolerance. Postharvest Biol. Technol. 92:157-163.

Xu, M.J., J.F. Dong, M. Zhang, X.B. Xu, and L.N. Sunday. 2012. Coldinduced endogenous nitric oxide generation plays a role in chilling tolerance of loquat fruit during postharvest storage. Postharvest Biol. Technol. 65:5-12.

Yang, H.Q., F.H. Wu, and J.Y. Cheng. 2011. Reduced chilling injury in cucumber by nitric oxide and the antioxidant response. Food Chem. 127:1237-1242.

Zhang, W.P., B. Jiang, W.G. Li, H. Song, Y.S. Yu, and J.F. Chen. 2009. Polyamines enhance chilling tolerance of cucumber (Cucumis sativus L.) through modulating antioxidative system. Scientia Hort. 122:200-208

Zhang, X.H., L. Shen, F.J. Li, D.M. Meng, and J.P. Sheng. 2013. Arginase induction by heat treatment contributes to amelioration of chilling injury and activation of antioxidant enzymes in tomato fruit. Postharvest Biol. Technol. 79:1-8.

Zhao, M.G., L. Chen, L.L. Zhang, and W.H. Zhang. 2009. Nitric reductase-dependent nitric oxide production is involved in cold acclimation and freezing tolerance in Arabidopsis. Plant Physiol. 151:755-767.

Zhou, Y.H., J.Q. Yu, W.H. Mao, L.F. Huang, X.S. Song, and S. Nogués. 2006. Genotypic variation of Rubisco expression, photosynthetic electron flow and antioxidant metabolism in the chloroplasts of chillexposed cucumber plants. Plant Cell Physiol. 47:192-199.

Zhu, L.Q., J. Zhou, and S.H. Zhu. 2010. Effect of a combination of nitric oxide treatment and intermittent warming on prevention of chilling injury of 'Feicheng' peach fruit during storage. Food Chem. 121:165-170. 